\title{
Nádasi Levente
}

\section{A growth accounting fejlődése a növekedéselméletek tükrében}

\begin{abstract}
Jelen írásban röviden bemutatom az egyes növekedéselméletek fejlődését, számba véve az egyes fejlödési szakaszokban a növekedés legfontosabb forrásainak tekintett tényezöket. Mivel a termelési függvény egyik fontos paramétere, a helyettesítési rugalmasság értéke nem egységnyi, ahogyan azt a nemzetközi vizsgálatokban alkalmazott Cobb-Douglas-termelési függvény feltételezi, és a helyettesítési rugalmasság értéke 1-töl eltérö is lehet, szükséges egy általánosabb, CES típusú (Constant Elasticity of Substitution állandó helyettesítési rugalmasságú) "termelési függvény"-család alkalmazása is. Technikai kérdésként felmerül a termelési tényezők csoportosítása is. A helyettesítési rugalmasság egyben hatékonysági tényező is, ezért a termelési függvény ezen jellemzője kiemelt szerepet kap az elemzésben. Végül összefoglalom azokat a legjelentősebb irodalmakat, amelyek föként a növekedés összetételével (growth accounting) foglalkoznak, és megpróbálnak választ találni arra a kérdésre, hogy mely faktorok játszanak jelentős vagy kevésbé jelentős szerepet a gazdasági növekedésben. A growth accounting erösen összekapcsolódik a növekedéselméletekkel, így a megfelelö pontokon visszautalok az egyes növekedéselméletekre is.
\end{abstract}

Journal of Economic Literature (JEL) kód: E13, O47

Kulcsszavak: növekedéselmélet, growth accounting, termelési függvény

A XX. században sokan próbálták megkeresni, mi okozza a gazdasági növekedést, jó-e, ha egy gazdaság növekszik, érdemes-e a két számjegyü növekedési ütemeket hajszolni, vagy az ilyesfajta növekedés úgyis mindig kifullad, és végül nem lesz fenntartható. Sokszor tapasztalhattuk, hogy a gazdasági csodák, azaz a magas növekedési ütemek azért fordulhattak elö, mert a növekedés nagyon alacsony szintről indult, például háború után újra kellett építeni az országot, és gyakran felütötte fejét az a jelenség is, hogy egy hosszabb, túl gyors, valószínüleg fenntarthatatlan növekedést követően a lufi kipukkadt, és gazdasági visszaesés következett be. Jelen dolgozatban arra próbálok választ keresni, hogyan lehet magas fenntartható növekedést elérni, és legfőképpen, milyen módszerrel lehet a gazdasági növekedést modellezni, valamint mi állhat a növekedés hátterében, milyen tényezők befolyásolják, azaz melyek a gazdasági növekedés mozgatórugói.

A rendkívül széles szakirodalomban erősen megoszlanak a vélemények a növekedés fö magyarázó változói tekintetében. Az 1960-as évek előtt a legtöbb szerző a tőkefelhalmozódás mellett tette le a voksát (Harrod 1939; Domar 1946; Solow 1956 1957), és ez abban az 
időben, az akkori vizsgálatok és idősorok alapján igaz is volt. A neoklasszikus modellben (Solow 1956) a termelési függvényben a tőke, a munka és az exogén technológia határozza meg az output szintjét. A growth accounting elemzések legtöbbször ezzel a reziduummal próbálják meghatározni a teljes tényezőtermelékenységet (TFP). A belső növekedést tehát túlnyomórészt a tőkefelhalmozódásnak tulajdonították, ennek megfelelően a megtakarítási ráta került a középpontba, hiszen ha az adott nemzetgazdaság többet takarít meg, akkor a több beruházás nyomán nagyobb lesz a tőkeállománya. Amikor azonban bizonyos fejlett országok tőkével való relatív ellátottsága már növekedett, és nem növekedtek tovább a korábbi ütemben, magyarázatukhoz újabb elméletek váltak szükségessé. Az egyik lehetőség a tőke értelmezésének kitágítása volt úgy, hogy abba beletartozik a humán tőke, a kapcsolati tőke, az infrastruktúra és bizonyos értelemben a tudás is. Tehát a hatékonyabb termelés vizsgálatánál ezek a tényezők is számba veendők a rendkívül magas hozzáadott érték magyarázatánál. Kétségtelen az is, hogy a technológia fejlődése, amit a különböző modellekben különbözőképpen kezelnek, az egyik legfontosabb hatékonyságot magyarázó tényező. Ha a technológiát olyan tudásként értelmezzük, amely megmutatja, hogyan kell hatékonyan termelni, akkor bizonyos értelemben a tőkejavakhoz sorolható (Romer 1986). A technológiát a legtöbb elmélet mégis maradékként, reziduumként kezeli, amit a reál termelési tényezők hatékonyságának növekedésével már nem tudunk magyarázni. A legtöbb szerző - többek között Caselli (2005) - az egyszerűség kedvéért elkülöníti a többi változótól, és teljes tényezőtermelékenységnek nevezi.

A nyitott gazdasági modellt is sokan vizsgálták, azt például, hogy a termelési tényezők szabad áramlása miként növeli a gazdasági jólétet (Romer 1990). Itt is fontos szerepet kap a fizikai tőke, a humán tőke és a technológiai előrehaladás, hiszen a gazdasági fejlődés föként ennek a három tényezőnek a működéséből ered. A technológiai fejlődést eddig a legtöbb közgazdasági elmélet nem kezelte endogén tényezőként, noha a technológiai haladás nem képzelhető el úgy, mintha csak úgy magától hullna az égből (Acemoglu 2009:862). Szükség van rá, hogy a technológiát belsővé tegyük, endogén változóként kezeljük. Innováció azért van, mert a profitmaximalizáló aktorok a saját érdekeiket nézik, azért fektetnek kutatásba, mert ez hosszú távon megéri nekik. A technológia fejlődése a gazdaság növekedésének elsőszámú forrása, és a különbözö technológiai szinttel magyarázható az országok közötti gazdasági teljesítmény is. A hangsúly azon van, hogy meg kell találni azt a szabályozási mechanizmust, ami megfelelö piaci környezetet biztosít ahhoz, hogy ösztönözze az innovációt, ugyanakkor mégse hozza monopolhelyzetbe hosszú távon az innovátort.

A szakirodalom némiképpen elhanyagolt, ám érdekes területe a termelési tényezők közötti helyettesíthetőség növekedésben játszott szerepének a vizsgálata. Egyes szerzők szerint a tőke és munka közötti helyettesítési rugalmasság egyben hatékonysági tényező is (Klump és Preissler 2000), és kiemelkedő hatása van a gazdasági növekedésre (De la Grandville 1989).

A növekedéselméleti ismeretek elsajátításához fontos alapot nyújt Philippe Aghion és Peter Howitt (1999) Endogenous Growth Theory címü müve, míg a növekedéselmélet tesztelése kapcsán Barro és Sala-i-Martín (1999) könyvében a fontos módszertani tanulságokon túlmenően arra vonatkozóan is fontos megállapításokat találunk, hogy milyen változók játszanak nagyobb szerepet a gazdasági növekedésben.

Empíria nélkül nehéz lenne következtetéseket levonni arra vonatkozóan, milyen fö változók húzódnak meg a gazdasági növekedés mögött, ezért illusztrációként néhány ilyen jellegü tanulmányt is segítségül hívtam (Henry 2007; Easterly és Levine 2001). 


\section{A növekedéselméletek fejlödése}

$\mathrm{Az}$ egyik legrégibb növekedési modell az úgynevezett AK-modell, amely lényegében azt állítja: ha a nemzetgazdaságban nagyobb a tőke mennyisége, nagyobb lesz a kibocsátásé is. Pontosabban a tőke mennyiségének növekedése és a gazdasági növekedés üteme között lineáris kapcsolat van. A feltevések szerint tehát a termelési függvény csak a tőkeállomány nagyságától függ:

$$
Y=F(K)=A K,
$$

ahol $\mathrm{Y}$ jelenti az outputot, $\mathrm{K}$ a tőke mennyiségét, A pedig konstans. Az, hogy mekkora ez a konstans, a tőke felhasználásának hatékonyságától függ.

Ezt a kapcsolatot a mai globalizált világban a sok zavaró változó miatt gyakran nehezen tudjuk kimutatni, de az AK-modellre ma már úgy tekintünk, mint sok más növekedési modell alapjára, amely többek között a Harrod-Domar-féle növekedéselmélet, a neoklasszikus növekedéselmélet, valamint a neoklasszikus modell függvénynek (Cobb és Douglas, 1928) is egy speciális esete.

Később az egyes elméletek azt mondták ki, hogy ez a kapcsolat nem lineáris, mivel a tőke határterméke csökken, ezért, ha növeljük a tőke felhasznált mennyiségét, nőni fog ugyan a kibocsátás, de egyre kisebb mértékben.

A Harrod-Domar-modell (Harrod 1939, valamint Domar 1946), ahol a feltevés szerint munkanélküliség van, az AK-modellnek egy korai változata, amely a következő termelési függvénnyel dolgozik:

$$
Y=F(K, L)=\min \{A K, B L\},
$$

ahol A és B konstans, a tôke és a munka hatékonyságát mérik, míg L a munka mennyiségét jelöli. Az egyenlet szerint a tőke és a munka között tökéletes kiegészítés figyelhető meg, vagyis e termelési tényezőket csak egy rögzített arányban érdemes felhasználni. Keynes szerint általánosságban az jellemző a gazdaságokra, hogy a tőke mennyisége lesz a szük keresztmetszet. Ha tehát állandó hatékonyságú technológia mellett a munkakínálat a tőke mennyiségéhez viszonyítva korlátlan mértékben van jelen, akkor az $A K<B L$, tehát a (2) egyenlet az (1) alakra fog egyszerüsödni. A cégek így $Y=A K$ mennyiségü outputot fognak termelni, és pontosan $(1 / \mathrm{B}) \mathrm{Y}=(1 / \mathrm{B}) \mathrm{AK}<L$ mennyiségü munkát fognak alkalmazni. Ha a megtakarítási ráta (s) konstans, akkor a tőkefelhalmozást leíró egyenlet a következő lesz:

$$
\dot{K}=s A K-\delta K,
$$

ahol $\delta$ a tőkelineáris amortizációja. A tőke növekedési üteme ezek szerint a következőképpen fog alakulni:

$$
g=\frac{\dot{K}}{K}=s A-\delta .
$$

Mivel a kibocsátás egyenesen arányos a tőke mennyiségével, g egyben az output növekedési üteme és az egy före jutó növekedési ütem is lesz. Ebben a modellben is, mint később több esetben is látni fogjuk, a megtakarítási ráta növekedése növeli a növekedési ütemet. A 
modell szerint azonban, ha a töke mennyisége elér egy bizonyos szintet, már nem ez lesz a szűk keresztmetszet, így a megtakarítási ráta növekedésével még magasabb növekedési ütem már nem érhető el.

A Frankel-Romer-modell (Frankel 1962 és Romer 1986) az AK-modellnek egy másik változata, amely viszont már teljes foglalkoztatottságot feltételez. A foglalkoztatottság növekedése helyett a technológiai tudás az a tényező, ami együtt nő a tőke mennyiségével. Ez a kijelentés azon alapul, hogy a technológiai tudás maga is tőkejószág. Hasonlóan kombinálható a többi termelési tényezővel az output kibocsátása érdekében. Ez a tudás gyakran nem egyből hasznosul a termelési folyamatban, de a felhalmozott tudás ugrásszerüen meg tudja növelni az output értékét, vagyis a jelenbeli tudás a tőkéhez hasonlóan csak a jövőben hasznosul. Már Frankel is észrevette ezt a hasonlóságot a tudás és a tőke között, hívja fel a figyelmet Aghion és Howitt (1999:25-29), ezért nem lehet fix együtthatókat rendelni a termelési tényezőkhöz. Ezért Frankel úgy képzelte el modelljét, hogy minden cégnek ugyanolyan Cobb-Douglas típusú termelési függvénye van. A j-edik cég termelési függvénye tehát a következőképpen néz ki:

$$
Y_{j}=\bar{A} K_{j}^{\alpha} L_{j}^{1-\alpha},
$$

ahol $K_{j}$ és $L_{j}$ a felhasznált tőke, illetve munka mennyiségét jelöli, $\alpha$ pedig konstans, és a tőke hozadékának arányát mutatja. Ha $\alpha<1$, márpedig ennek így kell lennie, akkor ez egyben a csökkenő határterméket is jelenti. Mivel minden cég azonos technológiával és tényezőárakkal szembesül, ugyanolyan arányban fogják termelési tényezőiket felhasználni, így az aggregát termelési függvény alakja:

$$
Y=\bar{A} K^{\alpha} L^{1-\alpha} .
$$

Könnyen belátható az is, hogy $\alpha=1$ esetén ismét az $Y=A K$ egyenlet adódik, tehát az AK-modell ennek is egy speciális esete. A Harrod-Domar-modellel ellentétben, ha itt nő a megtakarítási ráta, az permanensen fogja növelni a növekedési ütemet, akkor is, amikor már nem a tőke lesz a szük keresztmetszet. Romer modelljében a technológiai tudásnak szintén fontos szerepe van a gazdasági növekedésben. A termelési tényezők szabad áramlása és a gazdasági növekedés között itt is szoros kapcsolat van, mint ahogy már nagyon korán Ricardo is kifejtette, a komparatív előnyök alapján történő szakosodás megnöveli a termelékenységet. Igaz, Ricardo nem gazdasági növekedésről beszélt, mivel a szakosodást statikus módon képzelte el, ami csak egy egyszeri ugrásszerü növekedést eredményezhet a termelésben. Ezt Romer (1986) tovább finomította és egzakt matematikai formába öntötte, melynek részletezésére jelen keretek között nem térek ki.

A Solow- Swan- (Solow 1956; Swan 1956) és az AK-modellre manapság mint két egymással versenyző elméletre tekintenek, két lehetséges magyarázatként a növekedési folyamatra. Az eddigi modellek azt állították, hogy a tökefelhalmozódás a növekedés legfontosabb meghatározója, ezzel szemben a neoklasszikus elmélet azt állítja, hogy a növekedés többek között olyan külső tényezőktől függ, mint a népességnövekedés és a technológiai változás, ezért független a gazdaság strukturális jellemzőitől, amelyek csak az egy före jutó egyensúlyi jövedelmet határozzák meg. Ezzel szemben az AK-modell szerint ezek a strukturális jellemzők erősen befolyásolják a hosszú távú növekedési ütemet. 
Ezt az állítást Barro és Sala-i-Martín (1999:414-455) egy 1965-től 1985-ig terjedő idősor segítségével 90 országra empirikusan tesztelte. A panelelemzés eredménye azt mutatta, az átlagos GDP növekedése pozitívan korrelál az iskolázottsággal, a várható élettartammal, a beruházások volumenével, a kereskedelem liberalizálásával, és negatív kapcsolat figyelhető meg a kormányzati kiadásokkal. Talán elsőre úgy tünhet, ez az empirikus vizsgálat az AK-modellt támasztja alá, mert azt sugallja, hogy a strukturális változók hatással vannak a hosszú távú növekedési ütemre. Ez azért nincs így, mert a regresszió nem csak az okozatot mutathatja ki. Lehet tehát, hogy fordítva, pont a növekedés hat kedvezően ezekre a változókra, például a nagyobb GDP-nek nagyobb részét ruházzák be, vagy fordítják oktatásra, és így válik fejletté az ország.

További keresztmetszeti vizsgálatok azt támasztják alá, hogy a pénzügyi szektor fejlettsége kedvezően, a politikai instabilitás viszont kedvezőtlenül hat a növekedésre.

Easterley és Levine (2001) valamelyest árnyaltabban fogalmaz. Elképzelhető, hogy van köztük pozitív korreláció, de emellett még sok minden más is befolyással van a gazdasági növekedésre. A legtöbb szerző a növekedést leginkább az innovációnak tulajdonítja (Acemoglu 2009:840).

\section{A neoklasszikus modell}

A növekedéselméletek között talán a legátfogóbb képet a neoklasszikus modell tárja elénk (Solow 1956). Solow (1956) és Swan (1956) gyakorlatilag egy időben alkotott hasonló elméletet, ezért a neoklasszikus elmélet mindkettőjükhöz kötődik. Ez a modell az előzőekhez képest több tényezőt vesz figyelembe. Elméletük szerint, ha nem létezne technikai előrehaladás, akkor a termelési tényezők csökkenő határterméke határt szabna a növekedésnek. A modellnek az egyik része abban áll, hogy létezik egy állandó mérethozadékú aggregált termelési függvény. Első esetben jelentős egyszerüsítéseket teszünk, eltekintünk a népességnövekedéstől, és a munka-változót úgy kezeljük, hogy azt mondjuk, a gazdaságban egységnyi konstans munkakínálat áll rendelkezésre. Így a termelési függvény a következő egyszerü alakban írható fel:

$$
\mathrm{Y}=\mathrm{F}(\mathrm{K})
$$

Az egyszerü AK-modelltől eltérően itt nem tesszük fel, hogy a kibocsátás a tőke mennyiségének lineáris függvénye, de a függvényre vonatkozóan teszünk néhány korlátozó feltételt.

A (7) egyenlet azt fejezi ki, mekkora kibocsátást lehet elérni egy adott mennyiségü tőkével a tudásnak egy adott szintjén. Itt K nemcsak a fizikai tőke szintjét jelenti, hanem beleértendő a humán tőke is. Szintén feltesszük, hogy az összes rendelkezésre álló tőkét és munkát hatékonyan használják fel, tehát $F(K)$ nemcsak a termelési lehetőségeket jelenti, hanem azt, amit valóban meg is termelünk. Szintén feltesszük, hogy a parciális termelési függvény szigorúan monoton csökkenő határterméket mutat, és az Inada-feltételek teljesülnek rá (Aghion és Howitt 1999:11), azaz a függvény folytonos, és a töke határterméke végtelentől nulláig minden értéket felvesz: 


$$
\lim _{K \rightarrow \infty} F^{\prime}(K)=0 \text { és } \lim _{K \rightarrow 0} F^{\prime}(K)=\infty,
$$

amellett hogy ha $K=0$, akkor $F(K)=0$ is teljesül, illetve ha $K=\infty$, akkor $F(K)=\infty$ is igaz. Ezekben a feltételekben az is benne van, hogy a tőke mennyiségét egy ponton túl hiába növeljük, egy idő után már feleslegessé válik, mert nem tudjuk kihasználni. Mivel a modellben eltekintünk a népességnövekedéstől és a technológiai változástól, az egyetlen tényező, ami a növekedés faktora lehet, a tőkefelhalmozódás. A tőkefelhalmozódást leíró egyenlet, a korábbi jelölésekkel összhangban, ebben az esetben a következőképpen néz ki:

$$
\dot{K}=s F(K)-\delta K .
$$

A modell lényege, hogy ha a megtakarítási ráta nő, akkor emelkedik a beruházás, ami megnöveli a tőke állományát, így nő az egyensúlyi jövedelem.

Mivel a tôkefelhalmozás csak egy szintig lehetséges, lenni kell valaminek, ami ezután is fenntartható növekedést biztosít. Erre mutat rá Easterly és Levine (2001) is. Solow (1956) azt állítja, hogy mivel hosszú távon a tőke és a munka határterméke is csökkenő, ha nem lenne technológiai előrehaladás, akkor egy idő után megállna a növekedés. A technológiai fejlődést Solow azonban exogén tényezőnek tekintette.

\section{Innováció és tőkefelhalmozódás}

Eddig főként olyan modellekröl volt szó, amelyek a gazdasági növekedést a tökefelhalmozódással akarták magyarázni, vagy megfogalmazták ugyan, hogy a technológia fejlődése is szerepet játszhat, de külső változóként kezelték. A továbbiakban olyan modelleket vizsgálunk, amelyekben a technikai haladást megpróbálják belső változóvá tenni. Ha a tőkét tág értelemben vesszük, azaz a tudást és a humán tőkét is beleértjük, akkor máris közelebb kerültünk az endogén növekedéselmélethez. Ilyen értelemben a tőkefelhalmozódást és az innovációt hangsúlyozó modell nem két egymásnak ellentmondó elmélet, hanem különböző megközelítése ugyanannak a folyamatnak. A technológia gyakran olyan új formában ölt testet, amely a humán tőke vagy a fizikai tőke felhalmozódásán keresztül játszik szerepet.

Az endogén növekedéselmélet szerint az innováció belső tényező. A folyamatát úgy kell elképzelni, hogy a munkaerő egy részét termelésre, míg a másik részét kutatásra fordítják. $\mathrm{Az}$, hogy mennyit érdemes kutatásra fordítani, nagyrészt az adott iparág sajátosságaitól függ. Ebből az innovációból lesz később a felhalmozódó tudás. A tudás úgy hasznosul, hogy a termelési folyamatban részt vevő munkának megnöveli a termelékenységét. A tudás felhalmozódása a technológiát nem folytonosan növeli, hanem ugrásszerüen tapasztalhatók változások, ezért azt mondjuk, a technológiai szint időben nem csökkenő. Ez az állítás logikusnak tünik, hiszen minden időpontban választhatjuk azt a technológiát, ami már korábban a rendelkezésünkre állt.

A tőkefelhalmozódás és az innováció kiegészítik egymást (Aghion és Howitt, 1999:85). Egyik folyamat sem müködhet hosszú távon a másik nélkül. Innováció nélkül a csökkenő határtermék következtében a beruházások volumene lecsökkenne, beruházások nélkül pedig a növekvő tőkeköltség miatt az innováció visszaesne. A tőkefelhalmozás úgy ösztönzi az innovációt, hogy emeli az egyensúlyi profitot, az innováció pedig úgy segíti elő a tőkefelhalmozódást, hogy megemeli a termelékenységnövekedés ütemét. 
Romer (1986) szerint az innováció okozta gazdasági növekedés teljesen független a tőkefelhalmozás szintjétől.

\section{Technikai elörehaladás}

Az eddig tárgyalt egyszerü modellekben azt tettük fel, hogy a technológia szintje időben konstans, vagy olyan külső tényezőnek gondoltuk, amit belülről nem lehet befolyásolni. A népességnövekedést az egyszerüség kedvéért exogénnek tekintjük. Az egyszerübb modellek szerint tehát az egy före vetített változók értéke hosszú távon állandó. A modellnek ez a feltevése meglehetösen irreális. Az Egyesült Âllamokban például az egy före jutó növekedés két évszázadon keresztül pozitív volt. Technológiai elörehaladás hiányában a csökkenő hozadék nem teszi lehetővé, hogy ilyen hosszú ideig csak a tőkefelhalmozás tartsa fenn az egy före jutó növekedést. A neoklasszikus közgazdászok felismerték ezt a problémát, és beépítették a modellbe a technológia fejlödését. Ezzel valamelyest feloldották azt a paradoxont, hogy növekedés csak tőkefelhalmozódásból származhat.

Érdemes tehát kutatást végezni, aminek eredményeképpen a felhalmozódott tudás megnöveli a termelési tényezők hatékonyságát. A kutatás és fejlesztés történhet állami támogatással vagy a tőkeerősebb vállalatok maguk is végezhetnek kutatásokat. Gyakran azért lehet szükség állami támogatásra, mert erős piaci versenyben nincs megfelelő motiváció az innovációra. Ez a technológia közjószág-természetéből adódik. Ha az állam szabadalommal védi az új technológia elterjedését, akkor nagyobb technikai fejlődés jön létre, mert az innovátoroknak gazdasági haszna lesz a szabadalmi oltalom okozta monopolhelyzetből. Ha azonban nincs szabadalom, akkor gyorsabban szétterjed ugyan a tudás, de a gazdasági szereplőknek nem áll érdekében újítani. A modellben a technológia tiszta közjószágként van elképzelve, vagyis mindenki részesülhet belöle anélkül, hogy csökkentené a mások számára rendelkezésre álló mennyiséget.

Összességében azt állíthatjuk, hogy nemcsak a termelési tényezők mennyiségének felhalmozódása okoz növekedést, hiszen ez hosszú távon nem lenne fenntartható, hanem a termelési tényezők felhasználási hatékonyságának javulása is (Barro és Sala-i-Martín, 1999). A hatékonyságjavulást úgy is értelmezhetjük, hogy kevesebb tényezőre van szükség ugyanakkora kibocsátási szint eléréséhez, így tőkét, illetve munkát takaríthatunk meg. Ha a technológiával tőkét vagy munkát takarítunk meg, akkor azt mondjuk, a technológia semleges. A semleges technológiai haladás fogalmát többféleképpen is használhatjuk, attól függően, hogy milyen értelemben tekintjük semlegesnek.

Legyen $F(K, L, t)$ egy termelési függvény, ami nemcsak a 2 valós termelési tényezőtől, hanem "t"-tôl is függ. Az ilyen termelési függvényt nevezzük termelési folyamatnak, vagy röviden csak folyamatnak. A „t" változó itt nem feltétlenül az időt jelenti, hanem a technológiai fejlettség szintjeként is értelmezhetjük.

Ha a technológiai haladás olyan, hogy a határtermékek aránya változatlan marad egy adott tőke/munka arány mellett, akkor a termelési folyamatot Hicks-semlegesnek, vagy másképpen output-növelönek nevezzük. Tehát ha a technológia olyan, hogy a teljes tényezőtermelékenységet növeli meg, vagyis csak az izokvantokat számozza át, akkor ezt a következőképpen lehet felírni: 


$$
Y=F(K, L, t)=A(t) F(K, L),
$$

ahol „ $A$ ” egy olyan egyváltozós nemcsökkenő függvény, amely a technológia szintjét méri, csak az időtől függ, ennek megfelelően $\dot{A}(t) \geq 0$.

Ha a technológiai haladásra az jellemző, hogy a relatív inputarány $K F_{K} / L F_{L}$ változatlan marad egy adott munka/output arány mellett, akkor a termelési folyamatot Harrodsemlegesnek vagy munkanövelőnek nevezzük. Ebben az esetben tehát az innováció csak a munka hatékonyságát növeli meg, azaz:

$$
Y=F(K, L, t)=F(K, L \cdot A(t)),
$$

ahol szintén $\dot{A}(t) \geq 0$.

Ennek analógiájára: ha a technológia olyan, hogy a $K F_{K} / L F_{L}$ arány állandó marad adott munka/output arány mellett, akkor a termelési folyamatot Solow-semlegesnek vagy tőkenövelőnek nevezzük. Ebben az esetben az innováció csak a tőke hatékonyságát növeli meg.

$$
Y=F(K, L, t)=F(K \cdot A(t), L),
$$

ahol szintén $\dot{A}(t) \geq 0$.

\section{A CES típusú termelési függvény és a gazdasági növekedés kapcsolata}

A growth accounting elemzéseket az esetek túlnyomó többségében Cobb-Douglas típusú termelési függvény segítségével szokták elvégezni. Mivel különböző adatbázisok alapján rendelkezésre állnak a tőkeállományra, foglalkoztatásra, népességre és növekedésre vonatkozó adatok, a technológia fejlődését általában a növekedésnek azon részeként próbálják megbecsülni, amely nem a tőke- és a munkajövedelmek növekedéséből ered, tehát egyfajta maradékként. A Cobb-Douglas-termelési függvény használatával azonban van egy jelentős módszertani probléma. Ezzel a szerzők felteszik, hogy a termelési tényezők közötti helyettesítési rugalmasság egységnyi. Viszont az, hogy Cobb és Douglas az 1920as években az Egyesült Államokban ezt tapasztalta, még nem jelenti azt, hogy ez a világ bármely részén a 21 . században is így van. Ezért vizsgáljuk meg, hogy ugyan állandó, de nem egységnyi helyettesítési rugalmasságú, úgynevezett CES típusú termelési függvények segítségével miként lehet növekedéselméleti következtetéseket levonni.

A termelési tényezők hatékonyabb helyettesíthetősége és a gazdasági növekedés között mindig is szoros kapcsolatot tételeztek fel. Már több évszázaddal ezelőtt is gyanították, hogy a munka és a tőke közötti átváltás lehetősége nagyobb termelési hatékonyságot eredményez. Úgy sejtették, a helyettesítési rugalmasság egyben hatékonysági tényező is. Ezt a témát feszegeti Olivier de la Grandville (1989) helyettesítési rugalmasságra vonatkozó hipotézise is.

Azonban arra a kérdésre, hogy a helyettesítési rugalmasság milyen kapcsolatban van egy ország gazdasági növekedési ütemével, a pontos választ még nem sikerült megtalálni. Különböző növekedési elméleteket vetettek össze különböző CES típusú függvényekkel. $\mathrm{Az}$ állandó helyettesítési rugalmasságú termelési függvényeknek is több fajtája van, attól 
függően, milyen tulajdonságokat teszünk fel, illetve hogyan különítjük el egymástól a termelési tényezőket és a termelést befolyásoló egyéb tényezőket. Miután összevetették a különböző növekedési elméleteket külön-külön az egyes függvénytípusokkal, egymásnak teljesen ellentmondó eredményekre jutottak arra vonatkozóan, hogy a helyettesítési rugalmasság hogyan hat az egyensúlyi állapotra, illetve a hosszú távú növekedési rátára.

Elemeznünk kell tehát a helyettesítési rugalmasság és a gazdasági növekedés közötti összefüggést. Különböző variációk léteznek CES típusú termelési függvényekre. Az eddigiekben csak az ACMS-típusú termelési függvényt mutattuk be, mint az állandó helyettesítési rugalmasságú termelési függvény általános alakját, de ezen kívül még léteznek más változatok is állandó helyettesítési rugalmasságú termelési függvényekre. A különbség köztük nagyrészt a szinttényezők és a részesedési arányok értelmezése között van. Most négy releváns variációt írunk le ezek közül Klumpés Preissler (2000) alapján. A függvényeket ismét csak két termelési tényezőre, tőkére (K) és munkára (L) adjuk meg.

$\mathrm{Az}$ egyszerűség kedvéért még azt is feltesszük, hogy ezek a termelési függvények lineárisan homogének, vagyis állandó mérethozadékkal rendelkeznek.

Pitchford (1960) $)^{1}: \phi(K, L)=\left(\beta_{1} K^{-\rho}+\beta_{2} L^{-\rho}\right)^{-1 / \rho}$

Arrow, Chenery, Minhas és Solow (1961) ${ }^{2}$ :

$\phi(\mathrm{K}, \mathrm{L})=\mathrm{A}\left(\beta \mathrm{K}^{-\rho}+(1-\beta) \mathrm{L}^{-\rho}\right)^{-1 / \rho}$

David és Van de Klundert $(1965)^{3}: \phi(K, L)=\left[\left(\beta_{1} K\right)^{-\rho}+\left(\beta_{2} L\right)^{-\rho}\right]^{-1 / \rho}$

Barro és Sala-i-Martin (1995):

$\phi(K, L)=A\left\{\alpha(\beta K)^{-\rho}+(1-\alpha)[(1-\beta) L]^{-\rho}\right\}^{-1 / \rho}$

Mind a négy esetben a tőke és a munka között lévő helyettesítési rugalmasság a következőképpen számítható ki:

$$
\sigma_{\mathrm{KL}}=\frac{1}{1+\rho} .
$$

Pitchford (1960) szerint csak a termelési tényezők függenek a helyettesítési paramétertől, vagy, ahogy az előző fejezetben neveztük, a helyettesítési rugalmasságért felelős paramétertől.

Arrow, Chenery, Minhas és Solow (1961) ezen csak annyit változtattak, hogy azt mondták, létezik egy szinttényező is, ami a technológiai fejlettséget méri. Ezt nevezték hatékonysági tényezőnek, illetve a részesedési paraméterek összegét egységnyinek vették, mivel a tőketulajdonosok és a munkások csak egymás rovására részesedhetnek a jövedelemből.

Ezután 4 évvel David és Van de Klundert (1965) bevezettett egy fontos változtatást. Eddig ugyanis azt feltételezték, hogy a technológiai fejlődés minden termelési tényezőre egyformán hat. Ez azonban korántsem igaz.

Barro és Sala-i-Martin (1995) rámutatott arra, hogy a technológiai fejlődés nem minden szektorban egyforma mértékben növeli meg a helyettesítési rugalmasságot. Ezért tovább finomították a képletet, és további új együtthatókat vezettek be, amelyek a szektorok közötti egyenlőtlenségeket is magyarázzák. 


\section{A Solow-féle növekedési modell és a helyettesítési rugalmasság}

Most a Solow-féle növekedési modellt (Solow 1956) vesszük alapul, mely azóta is számtalanszor hivatkozási alap, pl. Rainer Klump és Harald Preissler (2000) közös cikke esetében is. Vegyünk egy egyszektoros gazdaságot. Legyen a termelés szintje Y. Tegyük fel továbbá, hogy ebben a gazdaságban tökéletes verseny van, illetve homogén terméket termelnek. Az Y elöállításához, mint már korábban is feltettük, két termelési tényezőt használunk, tôkét $(\mathrm{K})$ és munkát $(\mathrm{L})$. A Solow-modellben tehát a termelési függvény a következő alakot ölti: $Y=F(K, L)$, ami egyenlő a kínálattal. Az egy főre jutó termelést jelöljük y-nal, ahol $y=\frac{Y}{L}$. A modellben nemcsak a termelés volumenét fejezzük ki a munkaerő nagyságához viszonyítva, hanem valamennyi makroökonómiából jól ismert változót. Az egy före jutó mennyiséget mindig a megfelelő kisbetűvel jelöljük. Így az egy munkásra jutó tőke $\mathrm{k}=\frac{\mathrm{K}}{\mathrm{L}}$ értékkel egyenlő. Azért érdemes ezt a technikát alkalmazni, mert ezzel csökkenthetjük a változók számát. A kétváltozós termelési függvényünkből így egyváltozós függvény lett:

$$
\frac{\mathrm{Y}}{\mathrm{L}}=\mathrm{F}\left(\frac{\mathrm{K}}{\mathrm{L}}, 1\right)=\mathrm{y}=\mathrm{f}(\mathrm{k}) .
$$

Ennek a jelölésnek megfelelően legyen $\mathrm{s} \in[0,1]$ az outputnak az a hányada, amelyet nem fogyasztanak el (megtakarítási hányad), külső adottság. A piac megtisztulásának az a feltétele, hogy a beruházás egyenlő legyen a megtakarításokkal, vagyis $I=s Y$. Feltesszük továbbá a tőkének egy lineáris amortizációját, ennek a kulcsa legyen $\delta$. A népesség konstans arányban nő, legyen ennek az aránya n. Vessük össze a Solow-modellt egy normalizált ACMS-függvénnyel. Így a tőkefelhalmozást leíró egyenlet, amelyen nyomon követhetjük a tőkeintenzitás változását, $\dot{k}$ CES- típusú függvényre a következőképpen alakul:

$$
\left.\dot{k}=s A(\sigma)\left[\beta(\sigma) k^{-\rho}+(1-\beta(\sigma)) L^{-\rho}\right)\right]^{-1 / \rho}-(\delta+n) k .
$$

A (22) egyenletből következik, hogy k növekszik, ha a munkások megtakarításai sf(k) meghaladják a beruházást. Az egyensúlyi állapot a tőke mennyisége a népesség növekedési ütemének megfelelő mértékben növekszik. Az egyensúlyi állapotban a tőkeintenzitás $\mathrm{k}^{*}$ külső tényezőktől függ a következőképpen:

$$
\mathrm{k}^{*}=\left\{\frac{1}{1-\beta(\sigma)}\left[\frac{\delta+\mathrm{n}}{\operatorname{sA}(\sigma)}-\beta(\sigma)\right]\right\}^{1 / \rho}=\left[\frac{1-\beta(\sigma)}{\beta(\sigma)} \cdot \frac{\pi^{*}}{1-\pi^{*}}\right]^{-1 / \rho} .
$$

A (23) egyenletben $\pi^{*}$ jelöli az egyensúlyi állapotban a tőketulajdonosok jövedelmének arányát, amit a következőképpen adhatunk meg:

$$
\pi^{*}=\beta(\sigma)\left[\frac{k^{*}}{A(\sigma) y^{*}}\right]^{-\rho}=\beta(\sigma)\left[\frac{s A(\sigma)}{\delta+n}\right]^{-\rho} .
$$


Az egyensúlyi állapot létezésének és stabilitásának feltétele, hogy mindkét termelési tényezőt felhasználjuk a termeléshez. Ebből következik, hogy mindkét termelési tényezőnek pozitívan kell részesednie a megtermelt jövedelemből. Ez azt jelenti, hogy $\pi^{*}<1$. Abból, hogy sf(k) konkáv és $(\delta+n) k$ lineáris, az következik, hogy pontosan egy egyensúlyi pont létezik.

Cobb-Douglas-esetben $\sigma=1, \pi^{*}=\beta$. Ekkor tehát a kitevők nemcsak a parciális volumenrugalmasságot jelölik, hanem azt is megmutatják, hogy a termelési tényezők milyen arányban részesednek a jövedelemből. Belátható, a Cobb-Douglas-függvény esetében az egyensúly létezésének, stabilitásának és egyértelműségének feltételei mindig teljesülnek.

Ha $\sigma \neq 1$, akkor a létezés és a stabilitás a többi paramétertől, illetve azok kölcsönhatásaitól függ. Ekkor elképzelhetö, hogy elérjük az egyensúlyi helyzetet, majd elhagyjuk, a $\sigma$ megfelelő értékei mellett. Ha még pontosabban szeretnénk elemezni a növekedési küszöböt, akkor célszerű megkülönböztetni magas $\sigma>1$ és alacsony $\sigma<1$ helyettesítési rugalmasságú gazdaságokat. Ennek elemzése meglehetősen bonyolult, matematikailag nehezen modellezhetö.

Mindenesetre a tapasztalatok azt mutatják, magasabb $\sigma$ nagyobb valószínűséggel eredményez tartósan magas növekedési ütemet.

\section{A helyettesítési rugalmasság gyakorlati jelentősége}

A Solow-modell szerint, ha egy ország jövedelmének jelentős részét fordítja megtakarításra és beruházásra, nagy lesz az egyensúlyi tőkeállomány és a jövedelem. Ennek az elméleti következtetésnek fontos gyakorlati következményei vannak. Most már azt is tudjuk, hogy nemcsak a megtakarításoknak, hanem a helyettesítési rugalmasságnak is kiemelkedő szerepe van a magas jövedelemben, így közvetetten az adott gazdaság jólétében is. Azt a következtetést vonhatjuk le, hogy a normalizált CES-függvények esetében a helyettesítési rugalmasságban bekövetkezett növekedésnek pozitív hatása van az egyensúlyi tőkeállományra. Azt is tudjuk, csak egy magasabb $\sigma$ képes növelni az alkalmazkodás sebességét, ha az egyensúlyi tőkeállomány relatíve szükösebb, mint a munkaerö-állomány, mindkét tényezőt a kezdeti értékekhez viszonyítva.

Nézzünk most egy kicsit a Solow-féle növekedési modell mögé! Mi határozza meg a gyakorlatban a helyettesítési rugalmasság értékét? Arra, hogy miért hanyagolták el olyan sokáig a helyettesítési rugalmasságot mint a gazdasági növekedés egyik fontos jellemzőjét (egyes irodalmi források szerint mozgatórugóját), magyarázatként szolgálhat az a tény, hogy nehezen tudták a különböző CES-függvényeket formálisan kezelni. Ehhez még az is hozzájárult, hogy nem volt teljes egyetértés abban, hogy pontosan melyek a változó helyettesítési rugalmasság gazdasági okai. De la Grandville (1989) cikkében úgy aposztrofálta a helyettesítési rugalmasságot, mint a termelési rendszer hatékonyságának mértékét. Úgy sejtette, hogy az kelet-ázsiai csoda is főként ezzel magyarázható. Yuhn (1991) sikeresen tesztelte De la Grandville hipotézisét Koreára 1962 és 1981 között. Ebben az időszakban a koreai kormány áreltérítő politikát folytatott, a tőke árát mesterségesen alacsonyan tartották, és ez lehetett a legfőbb oka annak, hogy az országban magas volt az aggregált helyettesítési rugalmasság.

Milyen tényezők határozzák meg a helyettesítési rugalmasság értékét egy gazdaságban? Van különbség a termelési tényezők közötti helyettesítési rugalmasságok között is. Az 
iparágak között és iparágon belül ezek az értékek eltérőek lehetnek. A helyettesítési rugalmasság nagyon gyakran szubjektív, illetve nehezen mérhető tényezőktől függ. Ez még nehezebbé teszi a matematikai modellezést.

Végül a teljesség igénye nélkül felsorolunk néhány tényezőt (Klump és Preissler 2000), ami mind az iparágak közötti, mind az iparágon belüli helyettesítési rugalmasságot befolyásolhatja, hogy lássuk, mennyire összetett dologról van szó. Például többek között a szakszervezetek érdekeltek abban, hogy szabályozzák az iparágon belüli és iparágak közötti folyamatokat a tőke és a munka között. Emellett azonban számos tényező, mint például az iparági verseny ereje, a munkakultúra, egyes bürokratikus intézmények, a különböző országokban uralkodó eltérő tulajdonviszonyok, külső gazdasági hatások, a politikai berendezkedés, valamint a monetáris rendszer mind-mind hatással vannak a helyettesítési rugalmasságra.

\section{A technológia új értelmezései a gazdasági növekedésben}

Easterly és Levine (2001) empirikus elemzése azt hangsúlyozza ki, a tőkefelhalmozódás mellett valami más kell legyen a gazdaság motorja. A teljes tényezőtermelékenységet tekintik annak, feltéve hogy abban a változóban mutatkozik meg a technológiai fejlödés. Azt tapasztalták, az egyes országok jövedelemszintjei hosszú távon nemhogy nem közelednek, de még távolodnak is egymástól. A gazdagabb országok növekedési ütemei nem lassulnak, és a tőke hozadéka nem csökken. Ez az észrevétel a legkevésbé sem konzisztens azokkal az egyszerü modellekkel, melyek szerint az aggregált termelési függvényre állandó mérethozadék, a termelési tényezőkre csökkenő határtermék jellemző. Sokkal inkább összhangban van azzal a feltevéssel, hogy valami más állhat a siker hátterében. A növekedés időben meglehetősen ingadozik, míg a tényezőfelhalmozódás stabil képet mutat, ami szintén aláhúzza azt a feltevést, hogy valami mással kell magyarázni a gazdasági növekedést. A termelési tényezők oda áramlanak, ahol a legnagyobb a hozadékuk, ami azt sugallja, ezek a területek nem azért gazdagok, mert nagy a tőke mennyisége, hanem mert magas a TFP. Végül megállapítják, hogy az egy före eső jövedelem divergenciájában és a gazdasági tevékenység területi koncentrációjában a technológia növekvő hozadéka játszhat szerepet. Easterly és Levine (2001) nem vitatja, hogy a tőkefelhalmozódásnak bizonyos esetekben, egyes helyeken, iparágakban fontos szerepe lehet, elösegítheti a növekedést, de semmiképpen nem tekinthető a hosszú távú növekedés forrásának.

Comin, Hobijn és Rovito (2008) azt vizsgálta, hogy a technológiai különbségekkel magyarázhatók-e az országok közötti eltérö növekedési ütemek. Az egy före jutó reál GDP-t tekintették fő mutatónak. Mindezt 185 országra kiterjedő panelvizsgálattal tesztelték, és emellett azt is elemezték, hogy a technológia milyen gyorsan terjed el az országok között. A termelékenységi különbségek a TFP-különbségekből adódnak, de mivel az új technológia bevezetése után csak később kezd emelkedni a jövedelemszint, nehéz megállapítani, hogy pontosan milyen kapcsolat is van közöttük.

Az Egyesült Államok vezetőnek számít a technológia szintjét és fokát illetően. Számos ország több évtizedes késésben van vele szemben. Az országok közötti termelékenységi különbségek a technológia elterjedésének késése miatt léteznek. Amennyiben ez tényleg így van, akkor az új technológia befogadásának mértéke kulcskérdés lehet a növekedési 
folyamatok megértésében. Ez a technológiai késés mikroszinten is kimutatható, és ez vezet a TFP-eltérésekhez (Comin, Hobijn és Rovito 2008).

A legtöbb országban az tapasztalható, hogy míg egyes országok magas növekedési ütemeket és jelentős életszínvonalbeli javulást érnek el, mások stagnálnak, és még a lakosság alapvető szükségleteit sem tudják kielégíteni. A teoretikusok különböző módon magyarázzák az eltérő egy före eső reál GDP-szintet. Még manapság is nagy vita van abban, melyek a gazdasági növekedés legfontosabb meghatározói. Azt már eddig sikerült belátni, hogy mind a tökefelhalmozás, mind a technológiai fejlődés elengedhetetlen, de abban még mindig eltérnek a vélemények, melyiknek hol van nagyobb jelentősége, és a tőkefelhalmozódás valóban előfeltétele-e a technológiai fejlődésnek (Limam és Miller, 2004). Nyilvánvalóan számos tényezőtől függ, hogy végül melyik játssza a nagyobb szerepet. Míg a termelési tényezők felhalmozódása fontos lehet, addig az a kormányzati politika, ami megnöveli a tényezők kínálatát, éppen ellenkező hatást válthat ki. Afrikában például nagy általánosságban a munka hozzájárulása nagyobb a GDP-n belül. Az, hogy az afrikai országok viszonylag alacsony növekedési ütemeket érnek el, azzal magyarázható, hogy a munkapiacra irányuló gazdaságpolitika nem tud sikereket elérni abban, hogy nagyobb legyen a kibocsátás. A megnövekedett oktatás sem jelenthet kiutat, ha nincs mögötte a megfelelő oktatási és társadalmi politika. A fejlődő országoknak csökkentenie kell a nem megfelelő hatékonyságú állami vállalatok számát, továbbá az improduktív bürokráciát, ami a fejlődés akadályát jelenti (Limam és Miller 2004).

\section{A growth accounting elméletének fejlödése}

Az úgynevezett growth accounting elemzést arra szokták használni, hogy megbecsüljék, a tőke, illetve a munka milyen mértékben járul hozzá a megtermelt jövedelemhez. A tőkét és a munkát különböző módokon fel lehet osztani, attól függően, hogy hány változót vonunk be a modellbe, mennyire bonyolult elemzésre van szükség. A growth accounting elemzésnek megfelelően kifinomult változata választ adhat arra a kérdésre is, melyek a gazdasági növekedés legfontosabb tényezői, illetve mi a növekedés végső forrása. Ezt az elemzést az 50-es évek végén Solow (1957) kezdte el használni, és meglehetősen kevés változót és egyszerü termelési függvényt használt.

$$
Y=F(K, L)=A K^{\alpha} L^{1-\alpha},
$$

ahol Y jelenti a kibocsátást, Ka tőkeállományt, La munkások számát, $\alpha$ pedig az úgynevezett részesedési paraméter, ami ebben az esetben azt mutatja meg, hogy a tőketulajdonosok mekkora részét termelik meg a jövedelemnek. Ennek a függvénytípusnak sajátossága, hogy $\alpha$ konstans, mivel ha a tőke bérleti díát a határtermékén fizetik meg, akkor a tőkeállomány és a határtermékének szorzata pontosan $\alpha Y$ lesz, vagyis a tőketulajdonosok a jövedelem $100 \cdot \alpha$ százalékát „vihetik haza”. Az „A” paramétert, amit kezdetben szintén konstansnak gondoltak, szinttényezőnek nevezték. Konkrét értékének nincs különösebb jelentősége, kezdetben vehetjük akár egységnyinek is, a változásának mértéke azonban fontos információkat hordoz magában.

Ez az egyszerű hatványfüggvény nem más, mint a Cobb-Douglas típusú termelési függvény (Cobb és Douglas 1928). Ezt a függvényformát akkor kezdték el használni, amikor 
egy Douglas nevű szenátor idősoraiban azt figyelte meg, hogy mind a tőkejövedelem, mind a munkajövedelem a teljes kibocsátás stabil hányada, ezért azzal a kéréssel keresett fel egy Cobb nevü matematikust, árulja el, melyik az a függvényforma, amely konstans részesedést biztosít mind a munkásoknak, mind a tőketulajdonosoknak, és emellett még konstans skálahozadékú is (Mankiw 2005:105). Azért kezdték el ezt az állandó mérethozadékú alakot használni, mert jól viselkedő tulajdonságaiból következően jól lehetett vele modellezni a gazdasági növekedést makroszinten is. Ha a növekedést egy dinamikus modellben szeretnénk vizsgálni ${ }^{1}$, akkor elengedhetetlen, hogy a változók az időtől is függjenek, valamint a szinttényezőt is változónak kell tekinteni, hiszen pont ez mondja meg azon tényezők hatását, melyeket kihagytunk a modellből.

$$
Y(t)=F(A(t), K(t), L(t))=A K^{\alpha} L^{1-\alpha}
$$

Mivel már korábban is rendelkezésre álltak idősorok a gazdasági növekedésről, a foglalkoztatásról, valamint a tőkeállományról, meg lehetett vizsgálni, hogy a tőkeállomány és a munkások számának növekedése „kiadja-e” a kibocsátás növekedését. Végül azt mondták, hogy a növekedésnek az a része, amely nem magyarázható sem a tőkeállomány, sem a munkások számának növekedésével, az a technológia fejlődése, holott az több volt, mint technológia, hiszen az „A” paraméter növekedése minden egyéb tényező hozzájárulása volt a gazdasági növekedéshez, amelyet az alapmodellben figyelmen kívül hagytak. Ezt nevezték el később teljes tényezőtermelékenységnek (TFP).

$$
\dot{A} / A=\dot{Y} / Y-\alpha \dot{K} / K-(1-\alpha) \dot{L} / L
$$

A (3) egyenlet azt mutatja, hogy a teljes tényezőtermelékenység változását úgy kaphatjuk meg, ha a kibocsátás százalékos növekedéséből levonjuk a tőke és a munka százalékos növekedésének részesedési paraméterrel súlyozott átlagát (Solow 1957).

A Hicks-semleges függvényalak azt is feltételezi, hogy az idő múlásával a tőke és a munka hatékonysága azonos ütemben fejlődik, a humán tőke nélküli modelleknél ezt szokták feltenni (Mankiw, Romer és Weil 1992).

A humán tőke nélküli Hicks-semleges modellt alapul véve azt találták, hogy a fizikai tőke és a munka növekedése a gazdasági növekedésnek csak nagyon kis részét magyarázza. Mivel minden mást a technológiának tulajdonítottak, ezért azt mondták, hogy a technológiai elörehaladás bír a legnagyobb növekedésgeneráló hatással. A növekedéselmélet is ennek megfelelően fejlődött, a kezdetleges AK-modellek, amelyek azt hangsúlyozták, hogy a kibocsátás szintje arányos a tőkeállománnyal, arra engedtek következtetni, hogy a legfontosabb forrás a tőkefelhalmozódás. Az idősorok alapján ez még igaz is volt, hiszen az 1900-as évek elején a tőkefelhalmozódásnak még tényleg óriási szerepe volt. Azonban az 1960-as években, amikor az innováció elöretörésével a fejlett országok hatalmas növekedési ütemeket értek el, az AK-modellek csődöt mondtak. A kezdeti growth accounting vizsgálatok azt mutatták ki, hogy a technológia 80 százalékát magyarázza a növekedésnek (Abramivitz 1957).

\footnotetext{
1 A technológiai haladás irányát tekintve a termelési függvény lehet tőkenövelő, munkanövelö, outputnövelő illetve ezek kombinációi. A (2) termelési függvény outputnövelö, azaz Hicks-semleges (Barro és Sala-i-Martin, 1999).
} 
Később elkezdtek egyéb magyarázó változókat is bevonni a modellbe. Az egyik változó, amiről azt gondolták, hogy igenis nagy szerepe lehet a gazdasági növekedésben, és korábban Solow-maradékként a technológiához sorolták, az emberi tudás. Ha ezt most önálló változóként képzeljük el, akkor jobb eredményeket érhetünk el. Benhabib és Spiegel (1994) például olyan termelési függvényt konstruált, amelyben a fizikai tőke, a munka és a humán tőke teljesen egyenrangú változók egy Cobb-Douglas-termelési függvényben:

$$
Y(t)=F(K, L, H)=A K^{\alpha} L^{\beta} H^{1-\alpha-\beta} .
$$

Ez egy szintén állandó mérethozadékú termelési függvény, amelyben a TFP-nek már kisebbnek kell lennie, hiszen a maradék már nem tartalmazza a humán tőke GDP-hez való hozzájárulását sem. Ezt a módszert alkalmazva sikerült pontosabb képet kapni a növekedés fö összetevőiröl. Ez is egy lehetséges módszer, mindazonáltal a humán tőkét véleményem szerint a következőképpen célszerü beilleszteni a függvénybe ${ }^{2}$ :

$$
Y=F(K, L, H)=A K^{\alpha}(L H)^{1-\alpha} .
$$

Ezek szerint úgy képzeljük el a modellt, hogy a humán tőke gyakorlatilag úgy viselkedik, mint az egy hatékonysági egységre jutó munka, így a humán tőke nem a fizikai tőke, hanem a munka termelékenységét növeli meg. Azért is valószerü ez az elgondolás, mert az emberi tőke - amely fóként a tudást és az egészséget tükrözi vissza számszerüen - javulása nyilvánvalóan a munka termelékenységét fogja megnövelni. A humán töke mennyisége azért mégiscsak az oktatáshoz kötődik, és mivel nem tudjuk olyan objektív módszerekkel mérni, mint a fizikai tőkét és a munkát, ezért az átlagos iskolában töltött évek számával szokták becsülni (Kehoe és Prescott, 2007). Ez a proxy azonban gyakran félrevezetö lehet, mivel elöfordulhat, hogy az ok-okozati viszony pont fordítva van jelen. Elképzelhető ugyanis, hogy egy nemzet azért képes sokat költeni oktatásra, mert eleve gazdag, és nem attól lett gazdag, hogy sokat áldozott erre a területre, és polgárai sokat jártak iskolába. A TFP tulajdonképpen azt a hatékonyságot testesíti meg, amellyel a termelési tényezőket, vagyis a tőkét és a munkát használjuk.

A Cobb-Douglas-termelési függvényből származtatott TFP-különbségek arra is magyarázatot adhatnak, mi az oka az országok közötti tartós jövedelemkülönbségeknek, illetve miért van az, hogy egyes országok sokkal gazdagabbak, mint mások. Ha a TFP teljes mértékben nem is a technológia fejlettségét jelenti, valamiféle hatékonysági tényező lehet. Ha nem a változást tekintjük, hanem azt, milyen jövedelemszinten van az adott gazdaság, akkor nem a növekedési ütemet, hanem az adott jövedelemszintet kell megmagyarázni különféle magyarázó változókkal ${ }^{3}$ (Caselli 2005). Ebben az esetben a következő összefüggést kell valahogyan számszerüsíteni:

$$
\text { Jövedelem=F(Termelési tényezők, Hatékonyság), }
$$

vagyis egy gazdaságban megtermelt jövedelem nemcsak a termelési tényezők felhasznált mennyiségétől függ, hanem attól is, mennyire hatékonyan használják fel. Kezdetben azt

\footnotetext{
2 Legtöbbször ezzel a konstrukcióval találkozhatunk a szakirodalomban is (Caselli, 2005, valamint Bosworth és Collins, 2007).

${ }^{3}$ Az ilyen modellezést a szakirodalom development accountingnak vagy levels-accountingnak nevezi.
} 
gondolták, a tényezőfelhalmozás játssza a legnagyobb szerepet, és ez akkor még igaz is volt, hiszen egy bizonyos tényezőellátottság szükséges a nagy növekedés beindulásához, azonban amikor már adott a tényezőknek egy bizonyos szintje, egyre inkább az kezd el égető kérdéssé válni, hogy mennyire hatékonyan használják fel. Ezért is kaptak később a 80as években olyan eredményeket, hogy a technológia a növekedés 80 százalékát adja, mert a hatékonyság kezdett el fontosabb lenni. A „development accounting”-ban is egyértelmüen a hatékonyság a kulcskérdés.

Használjuk tehát azt a Hall-Jones-féle (1999) termelési függvényt, amelyet Caselli (2005) is használ:

$$
Y=A K^{\alpha}(L h)^{1-\alpha},
$$

ahol Y továbbra is a gazdaság jövedelmét jelenti, $\mathrm{K}$ az aggregált fizikai tőke, valamint Lh a minőséggel korrigált munkaerő, vagyis a munkások száma (L) szorozva az átlagos humán tőkével. Az átlagos humán tőke az egy munkásra jutó humán tőkét jelenti. Az a kitevő továbbra is konstans. Az A paraméter a teljes tényezőtermelékenység, ami a hatékonyságot, az A növekedése a technológia fejlődését, a hatékonyság javulását jelenti. Ha a (31) egyenletben mindkét oldalt elosztjuk a munkások számával, akkor a következő összefüggést kapjuk:

$$
y=A k^{\alpha} h^{1-\alpha},
$$

ahol y az egy munkásra jutó termelést, $\mathrm{k}$ pedig az egy munkásra jutó tőkét mutatja. Így az egy munkásra jutó GDP szintjét ki tudjuk számolni az egy munkásra jutó tőke és az egy munkásra jutó humán tőke segítségével, ha ezeken felül ismerjük az a-t. Ezenkívül, ha az egy munkásra jutó jövedelmet is ismerjük, akkor ellenőrizhetjük a modell illeszkedését.

Az elemzéshez szükséges adatokat két különböző adatbázisból nyerhetjük ki. Az egyik a Penn World Tables 6.3 verziója (PWT63: Heston, Summers és Aten 2002), amely tartalmazza többek között országonként az összes releváns fontos makroökonómiai mutatót, tehát a fizikai tőkét, a kibocsátást és a munkások számát is, amelyre most kiemelt szükségünk van. A humán tőke adatait az oktatottságból, tehát az átlagos iskolában töltött évek számából becsülhetjük, melyhez a Barro-Lee-féle (2001) adatbázist hívom segítségül.

$\mathrm{Az}$ egy munkásra jutó output (y) becslésénél egyszerü dolgunk van, a PWT63 adathalmaznak, van egy olyan oszlopa, hogy RGDPWOK, amely pontosan az egy munkásra jutó reál GDP értékét mutatja meg USA dollárban kifejezve.

Az egy munkásra jutó tőke adatait már nem találjuk meg ilyen egyszerủen, azt már nekünk kell becsülni az eredeti adathalmazból. Ehhez először a tőkeállomány mennyiségét kell megbecsülni, ami a beruházási adatokból származtatható, mivel a tőke beruházással jön létre. Viszont mivel nem állnak rendelkezésre nagyon korai időpontból adatok, szükséges egy kezdeti tőkeállomány becslése is, ráadásul azzal is számolni kell, hogy az egyes országoknál a túl korai adatok már nem megbízhatóak. A kezdeti tőkeértéktől kezdve hozzá kell adni kumulálva a beruházási adatokat, és le kell vonni belőle az előző évi tőkeállomány amortizációját. Tehát az adott évben a tőkeállományt a következő formulának megfelelően kell kiszámolni: 


$$
K_{t}=I_{t}+(1-\delta) K_{t-1},
$$

ahol az I a beruházást jelenti, $\mathrm{t}$ alsó index az adott mennyiség t-edik időpontbeli értékét mutatja, míg $\delta$ nem más, mint az amortizációs ráta. A tőkeállomány kezdeti értékét úgy kapjuk meg, hogy vesszük azt a legkorábbi beruházási adatot az idősorban, amely még elérhetö, és ezt osztjuk el az értékcsökkenés és az egész idősor alatti növekedési ráták számtani átlagának összegével:

$$
K_{0}=I_{0}(g+\delta) \text {. }
$$

A szakirodalomban a legtöbbször a $\delta=0,06$ értéket szokták feltenni, és nekem sincs komolyabb okom arra, hogy más értékkel számoljak. Nyilván k értéke úgy kapható meg, ha K értékét elosztjuk a munkások számával (L). Ezt az adatot ugyan a PWT nem közli, de ez is kiszámítható a következőképpen:

$$
\frac{R G D P P C * P O P}{R G D P W O K}=\frac{\frac{Y}{P O P}}{\frac{Y}{L}} * P O P=L .
$$

Ez a tört azt jelenti, hogy az egy före jutó GDP-t el kell osztani az egy munkásra jutó GDPvel, és ezt meg kell szorozni a népességgel. Így kapjuk meg a munkások számát.

A humántőke-adatokat Barro és Lee (2001) adatbázisából becsüljük Hall és Jones (1999) módszere szerint az iskolázottsági adatokból:

$$
h=e^{\varphi(s)},
$$

ahol s az átlagosan iskolában töltött évek számát jelenti a 25 éven felüliek körében, míg $\varphi(s)$ ennek egy szakaszonként lineáris függvényét, aminek a meredeksége 0,13 , ha $s \leq 4,0,10$, ha $4<s \leq 8$ és 0,07 , ha $8<s$. Adott termelési függvény mellett és tökéletes versenyt feltételezve a termelési tényezők és a termékek piacán is, reális azt feltételezni, hogy a munkások iskolában töltött éveinek száma arányos a humán tőke nagyságával.

\section{Konklúzió}

Jelen tanulmány összefoglalta az alapvető növekedéselméleteket, és ezen keresztül bemutatta, hogyan fejlődött az elmélet, valamint hogy az egyes fejlödési szakaszokban mit tekintettek az egyes elméletek a növekedés legföbb forrásának. Kezdetben a tőkefelhalmozás tünt a legfontosabb tényezőnek, az empirikus vizsgálatok is ezt igazolták, majd amikor a tőkefelhalmozódás elért egy bizonyos szintet, lecsökkent a határterméke, és egyre inkább a technológiai haladásnak tulajdonítottak fontosabb szerepet.

További cél volt, hogy bevezetést nyújtson a gazdasági növekedés elemzési technikáinak vizsgálatába, és valamelyest összehasonlítsa azokat. Az egyik legnépszerűbb módszer, a közismert growth accounting elemzés, melyben a teljes tényezőtermelékenységet CobbDouglas típusú termelési függvényből maradékként becslik. Ennek lehetne véleményem 
szerint egy alternatívája, és - új kutatási irányként említem meg - a növekedés CES típusú termelési függvénnyel való számbavétele. A TFP helyett a helyettesítési rugalmassággal is lehetne mérni a technológia fejlődését. A módszer nehézsége a termelési tényezők súlyozása kapcsán jön elö, mivel a gyakorlatban nehéz megmondani, hogy egy termelési folyamat milyen mértékben output-, tőke- vagy munkanövelö, mennyire kiegyensúlyozott a termelési tényezők mennyiségének és hatékonyságának növekedése. Klump és Preissler (2000) munkája alapján azt a következtetést vontam le, hogy a helyettesítési rugalmasság, amely a termelési függvény egyik objektíven mérhető paramétere, egyben hatékonysági tényező is, és nagyobb értéke nagyobb valószínűséggel magasabb növekedési ütemet eredményez. További fontos kutatási területnek tekintem annak elemzését, hogy az említett intézményi tényezők pontosan milyen módon befolyásolják ennek a paraméternek az értékét. A fent említett cikkek és saját vizsgálataim alapján kitünik, a TFP növekedése, azaz a technológiai fejlődés gazdasági növekedésre gyakorolt hatása a XX. század folyamán egyre jelentősebbé vált a tőkeakkumuláció szerepének enyhe háttérbe szorulása mellett.

A growth accounting és a bekapcsolt újabb változók segítségével egyes pontokon megpróbáltam kapcsolatot keresni a növekedéselméletek és az egyes technikák között, hiszen a két elmélet egymással összefüggésben fejlödött: a hatvanas évektől bekapcsolt humán tőke mint változó eredményeképpen a növekedéselméletben új irányzatok jelentek meg, amelyekben e tényező lényeges hangsúlyt kapott, és az endogén növekedéselmélet egyik legfontosabb elemévé vált.

\section{Irodalomjegyzék}

Abramivitz, M. (1957): Resources on Output Trends in the United States since 1870. American Economic Review 46:5-23

Acemoglu, D. (2009): Introduction to Modern Economic Growth. Princeton University Press, New Jersey

Aghion, P. - Howitt, P. (1999): Endogenous Growth Theory. The MIT Press, Cambridge, Massachussetts, London

Arrow, K. J. - Chenery, H. B. - Minhas, B. S. - Solow, R. M. (1961): Capital-labor substitution and economic efficiency. The Review of Economics and Statistics 43:225-250.

Barro, R. J. - Sala-i-Martín, X. (1999): Economic Growth. McGraw-Hill, New York.

Caselli F. (2005): „Accounting for Cross-Country Income Differences”, Handbook of Economic Growth. In: Philippe Aghion és Steven Durlauf

Cobb, C. W. - Douglas, P. H. (1928): A theory of production. American Economic Review 18:139-165.

Comin, D. - Hobijn, B. - Rovito, E. (2008): Technology usage lags. Journal of Economic Growth 13, 237-256

Domar, E. (1946): „Capital Expansion, Rate of Growth and Employment”. Econometrica 14:137-47.

La Grandville, de, O. (1989): In Quest of the Slutsky Diamond, The American Economic Review 79:468-481.

Easterly, W. - Levine, R. (2001): „It's Not Factor Accumulation”: Stylized Facts and Growth Models.” The World Bank Economic Review 15 2: 177-219.

Frankel, M. (1962): The Production Function in allocation and Growth: A Synthesis. American Economic Review 52:995-1022.

Harrod, R. F. (1939): „An Essay in Dynamic Theory” Economic Journal 49, 14-33.

Henry, P. B. (2007): Capital Account Liberalization: Theory, Evidence and Speculation. Journal of Economics Literature 45, 4: 887-935.

Kehoe, T. J. - Prescott, E. C. (2002): „Great Depressions of the Twentieth Century”, Review of Economic Dynamics, 5, 1:1-18.

Klump, R. - Preissler, H. (2000): CES Production Functions and Economic Growth, Scandinavian Journal of Economics 102:41-56. 
Limam, Y. R. - Miller, S. M. (2004): Explaining Economic Growth: Factor Accumulation, Total Factor Productivity Growth, and Production Efficiency Improvement, Quarterly Review of Economics and Finance, Working Paper 2004-20,

http://digitalcommons.uconn.edu/cgi/viewcontent.cgi?article=1134\&context=econ_wpapers (200906-17)

Lucas, R. E. (1988): „On the Mechanics of Economic Development.” Journal of Monetary Economics 22:3-42.

Mankiw, N. G., D. Romer, and D. N. Weil (1992): „A Contribution to the Empirics of Economic Growth.” The Quarterly Journal of Economics 107, 2:407-437.

Romer, P. M. (1986): „Increasing Returns and Long-Run Growth.” Journal of Political Economy 94:10021037.

Romer, P. M. (1990): „Endogenous Technological Change.” Journal of Political Economy 98:71-102.

Solow, R. (1956): A Contribution to the Theory of Economic Growth, Quarterly Journal of Economics 70:6594.

Solow, R. (1957): Technical Change and the Aggregate Production Function. Review of Economics and Statistics 39, 3:321-320.

Yuhn, K. (1991): Economic Growth, Technical Change Biasis, and the Elasticity of Substitution: A Test of de La Grandville-Hypothesis. Review of Economics and Statistics, 73:340-346. 